\title{
Estimation of Daily Sunshine Duration from Terra and Aqua MODIS Data
}

\author{
H. M. Kandirmaz and K. Kaba \\ Department of Physics, Faculty of Sciences and Arts, Cukurova University, 01330 Adana, Turkey \\ Correspondence should be addressed to H. M. Kandirmaz; mkandirmaz@cu.edu.tr
}

Received 2 February 2014; Revised 29 March 2014; Accepted 31 March 2014; Published 15 April 2014

Academic Editor: Luis Gimeno

Copyright (c) 2014 H. M. Kandirmaz and K. Kaba. This is an open access article distributed under the Creative Commons Attribution License, which permits unrestricted use, distribution, and reproduction in any medium, provided the original work is properly cited.

\begin{abstract}
Some studies have shown that the estimation of global sunshine duration can be done with the help of geostationary satellites because they can record several images of the same location in a day. In this paper, images obtained from the MODIS (Moderate Resolution Imaging Spectroradiometer) sensors of polar orbiting satellites Aqua and Terra were used to estimate daily global sunshine duration for any region in Turkey. A new quadratic correlation between daily mean cloud cover index and relative sunshine duration was also introduced and compared with the linear correlation. Results have shown that polar orbiting satellites can be used for the estimation of sunshine duration. The quadratic model introduced here works better than the linear model especially for the winter months in which very low sunshine duration values were recorded at the ground stations for many days.
\end{abstract}

\section{Introduction}

The amount of sunshine duration incident on the Earth's surface is an important meteorological parameter due to its usage in many applications [1-7]. In general, there are much more meteorological stations which measure air temperature and precipitation than those for solar radiation and sunshine duration. For instance, in Turkey, while air temperature values have been collected at more than 400 meteorological stations, solar radiation and sunshine duration have been measured at only 163 and 192 stations over long periods, respectively [8]. According to Environment Canada [9], there are 320 stations with sunshine duration measurements in Canada which are 1/7 times less than those that collect precipitation and air temperature data. There are approximately 400 stations for the whole of Africa and only 34 stations in Egypt in which sunshine duration data is recorded $[10,11]$. Contrary to the common belief, networks of sunshine duration are still sparse and insufficient due to mostly geographic and financial reasons especially for developing countries. Although the best way of collecting of any meteorological data is to record the data directly using proper instruments at meteorological stations, these are point measurements which imply that recorded data have high temporal resolution but low spatial resolution. Values belonging to the regions in the vicinity of the stations are generally estimated by extrapolation and interpolation methods. But, since the spatial distributions of the existing stations generally are not homogeneous, the values from these methods may be questionable. Up to now many studies have been reported for the estimation of global solar radiation, but unfortunately in spite of its vital importance only a limited number of studies have been available in the literature for the determination of global sunshine duration and its spatial distribution and variation throughout time. The main reason why this happens is that the data recorded by sunshine recorders are more reliable than those of solar radiation data recorded by actinographs [8].

Geostationary and polar orbiting satellites can observe and take the images of the areas under the coverage of the sensors boarded on them. These images have been used for many different purposes and also for estimating global solar radiation [12-20]. On the other side, only a few studies have been reported the estimation of global sunshine duration using satellite data. Kandirmaz (2006) proposed a simple linear model to predict the daily sunshine duration and 
constructed spatially continuous sunshine duration maps for Turkey using a time series of Meteosat C3D visible type images [21]. A simple model was developed by Good for estimating sunshine duration over the United Kingdom from time series of cloud type data from the Spinning Enhanced Visible and Infrared Imager (SEVIRI) which is an instrument onboard the Meteosat Second Generation (MSG) satellite and records data every 15 minutes [22]. Shamim et al. have used hourly $2.5 \mathrm{~km} \times 2.5 \mathrm{~km}$ Meteosat images for estimating sunshine duration on the Brue Catchment [23]. Bertrand et al. have used two different approaches combining ground station and MSG data to estimate daily sunshine duration over Belgium [24]. As one can notice, in all these studies, estimations were performed using the data of a geostationary satellite which makes repeated observations over a given area. Geostationary satellites have low spatial resolution due to their high orbit altitude whereas polar orbiting satellites have high spatial resolution but they can view most of the Earth surface only two times in a day (one in daylight and one in darkness). In this work, we tried to estimate daily global sunshine duration using the data of a polar orbiting satellite and for this purpose Moderate Resolution Imaging Spectroradiometer (MODIS) images have been used.

\section{Data and Methodology}

Two polar orbiting satellites Aqua and Terra, carrying the same MODIS sensors, orbit in two distinct paths with a swath width of $2330 \mathrm{~km}$ and view the entire surface of the Earth every one to two days. Aqua crosses Equator at 1:30 p.m. on the descending mode while Terra crosses Equator at 10:30 a.m. on the ascending mode. Thus a morning and/or afternoon observation for any place on the Earth or the atmosphere below sensors is possible using the images of both of the satellites. MODIS has 36 spectral bands varying from 0.41 to $14.385 \mu \mathrm{m}$. The spatial resolution of bands 1 and 2 is $250 \mathrm{~m}$, bands 3 to 7 is $500 \mathrm{~m}$, and the rest of the bands is $1 \mathrm{~km}$. Bands 1 to 19 and 26 are produced from daylight reflected solar radiation and are known as reflective solar bands. Bands from 20 to 25 and 27 to 36 are produced by thermal emissions of the day and night and are known as thermal emissive bands. For the current study, we have used MOD02QKM (Terra file) and MYD02QKM (Aqua file) daily scenes as data which are calibrated and geolocated of MODIS LEVEL 1-B output products having $250 \mathrm{~m}$ spatial and 16-bit radiometric resolution. Daily sunshine duration data have been obtained from State Meteorological Service (TSMS) of Turkey. Data of Istanbul, Ankara, Samsun, Izmir, Antalya, Konya, S.Urfa, Erzincan, and Muş stations were used to find a unique correlation for Turkey and data of Kocaeli, Bursa, Balikesir, Eskişehir, Afyon, Denizli, Niğde, Sivas, Malatya, K.Maras, G.Antep, Diyarbakır, Van, Hakkari, Trabzon, and Rize stations were used to test the success of the derived correlations. The geographical distributions of stations are given in Figure 1. As one may notice these stations are spread over Turkey and we expect that these stations represent all possible climatic characters of the whole country.

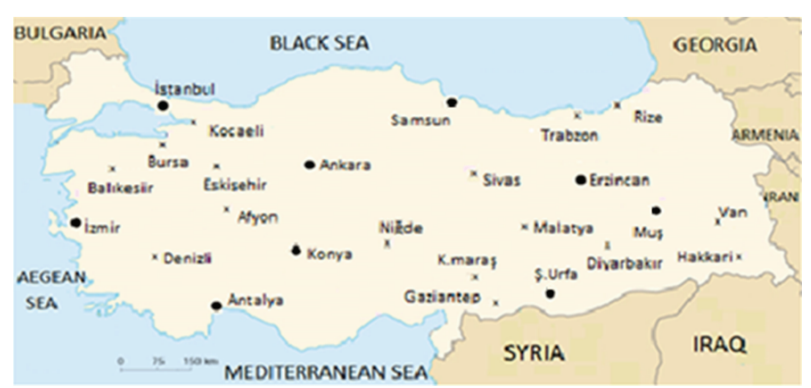

FIGURE 1: The geographical distributions of nine calibration $(\bullet)$ and 16 testing $(\mathrm{x})$ stations in Turkey.

Maximum possible sunshine hours or day length depend on the latitude of site and solar declination angle can be computed as [25]

$$
S=\left(\frac{2}{15}\right) \operatorname{arcos}(-\tan \delta \tan \psi),
$$

where $\psi$ is the latitude of location in the range $-90 \leq \psi \leq+90$ and $\delta$ is the solar declination given by

$$
\delta=23 \cdot 45 \sin \left(\frac{360}{365}(284+n)\right)
$$

and $n$ is the number of days of the year starting from first of January.

The amount of sunshine duration reaching an area at ground depends on the astronomical factors (sun's elevation and azimuth and the sun-Earth distance) and the atmospheric constituents. Clouds, consisting of liquid water droplets or ice particles, are greatly responsible for preventing incoming solar rays from reaching the Earth's surface as compared to other constituents. Interactions of clouds with solar rays depend on size and shape of droplet or particles, total mass of water, and spatial distribution. Since the physical explanation of these interactions is not very easy, the relation between cloud cover and sunshine duration is generally done by using empirical models [11, 21, 26-28]. Fortunately, the motion of the clouds can be recorded by satellite sensors and thus it is possible to calculate the cloud cover index over any area under the coverage. It has been shown that satellitederived cloud cover index can be calculated from the well known relation as follows [14]:

$$
n=\frac{\rho-\rho_{\mathrm{ga}}}{\rho_{\mathrm{cm}}-\rho_{\mathrm{ga}}} .
$$

Here $\rho$ is thereflectance of the pixel at any time, $\rho_{\mathrm{ga}}$ is the reflectance of the same pixel in the absence of cloud, and $\rho_{\mathrm{cm}}$ is the mean reflectance of the pixels covered by cloud. $\rho_{\mathrm{ga}}$ and $\rho_{\mathrm{cm}}$ can be derived from time series images by employing an adaptive iterative filtering. Daily mean cloud cover index, $n_{m}$, of each pixel can be calculated from the following relation [21]:

$$
n_{m}=\frac{1}{z} \sum_{k=1}^{k=z} n_{k},
$$


TABLE 1: Regression coefficients and coefficients of determinations of quadratic and linear models for each month.

\begin{tabular}{lccccccc}
\hline & \multicolumn{3}{c}{ Quadratic } & \multicolumn{2}{c}{ Linear } & \multicolumn{2}{c}{$R^{2}$} \\
\hline January & $a$ & $b$ & -1.8796 & 0.8093 & 0.7447 & -0.9136 & 0.6677 \\
February & 1.0923 & -1.7284 & 0.8247 & 0.7336 & -0.8273 & 0.6836 \\
March & 0.9473 & -1.6835 & 0.9019 & 0.7941 & -0.9714 & 0.7183 \\
April & 0.8181 & -1.6299 & 0.8449 & 0.7406 & -0.8778 & 0.6785 \\
May & 0.9004 & -0.9260 & 0.8514 & 0.7272 & -0.9212 & 0.7803 & 0.6509 \\
June & -0.0061 & -0.5304 & 0.8437 & 0.6414 & -0.7493 & 0.8639 \\
\hline
\end{tabular}

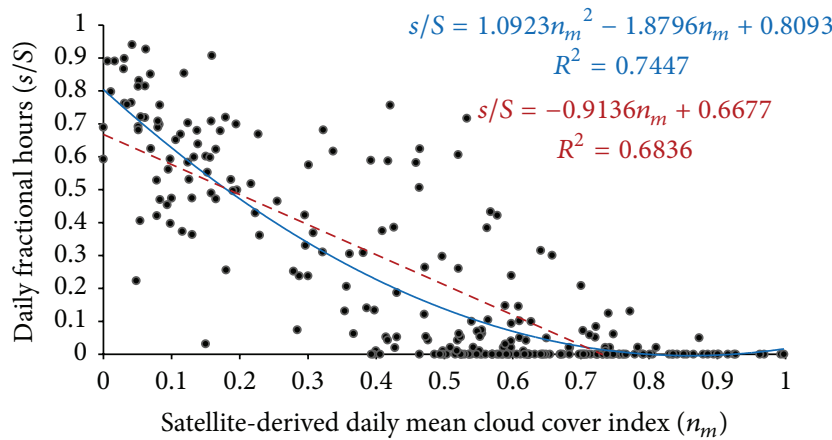

Figure 2: Quadratic and linear relationships between daily fractional sunshine hours and satellite-derived daily mean cloud cover index using data of nine calibration stations for January 2004.

where $z$ is the total number of images recorded by the satellite sensor in a day and $n_{k}$ is the cloud cover index of $k$ th image. The maximum value of daily mean cloud cover index is 1 (pixel is totally covered by cloud) and the minimum value is 0 (no cloud cover). That is, it ranges from 0 to 1 . A linear relationship between daily relative sunshine duration and satellite-derived daily mean cloud cover index is defined as [21]

$$
\frac{s}{S}=a n_{m}+b
$$

where $a$ and $b$ are regression parameters which are functions of location, season, and state of the atmosphere. Equation (5) implies that if the cloud cover ratio over an area is known then it is possible to estimate the sunshine duration over that area or vice versa. On the other hand, in the present study, it has been experimentally concluded that such a formulation was not adequate for the days of winter in which generally the sky was fully overcast (sunshine duration measured as 0 and/ordaily mean cover indexes were calculated as nearly 1). For such cases linear model could produce negative sunshine duration values, which were meaningless, for many days for many stations. Thus, a new correlation was needed and a quadratic formula was proposed as follows:

$$
\frac{s}{S}=a n_{m}^{2}+b n_{m}+c
$$

where $a, b$, and $c$ are again regression coefficients to be determined. As can be seen from Figure 2 the quadratic model appears to fit data better than the linear model with a higher coefficient of determination value.

\section{Results and Validation}

First of all, daily mean cloud cover index values were calculated from the MODIS MOD02QKM and MYD02QKM data. Using the measured sunshine data of nine stations (calibration stations) the statistical correlations were constructed for each month. Regression coefficients and coefficients of determination belonging to each month were given in Table 1 .

Sunshine duration values were calculated for calibration and testing stations by using the obtained correlations and results compared to the ground measurements. Accuracies of the models were tested with three statistical indices: coefficient of determination $\left(R^{2}\right)$, mean biased error (MBE), and root mean square error (RMSE). These indices are defined as follows:

$$
\begin{gathered}
R^{2}=\frac{\left[\sum_{i}^{n}\left(Z_{i}-\bar{Z}\right)\left(O_{i}-\bar{O}\right)\right]^{2}}{\sum_{i=1}^{n}\left(Z_{i}-\bar{Z}\right)^{2} \sum_{i=1}^{n}\left(O_{i}-\bar{O}\right)^{2}}, \\
\text { RMSE }=\sqrt{\frac{\sum_{i=1}^{n}\left(Z_{i}-O_{i}\right)^{2}}{n}}, \\
\operatorname{MBE}=\frac{\sum_{i=1}^{n}\left(Z_{i}-O_{i}\right)}{n},
\end{gathered}
$$

where $n$ is the total number of observations, $Z_{i}$ is the estimated sunshine duration (using models), $O_{i}$ is the observed sunshine duration (measured by sunshine recorder), and $\bar{Z}$ and $\bar{O}$ are the average values. $R^{2}$ gives information about how well a model fits to data and its ideal value is 1 . RMSE and $\mathrm{MBE}$ are measures of how close/far a fitted line is to data points and deviation between model results and measured data, respectively. While RMSE gives information on the short-term performance of the models, MBE does the same on the long-term. Ideal values of RMSE and MBE are certainly zero and lower values of them indicate that estimated values are consistent with those of measured ones. On the other hand, a positive value of $\mathrm{MBE}$ shows the amount of overestimation and a negative value shows the amount of underestimation.

The values of statistical indicators show that the quadratic correlations explained the statistical relation between the 


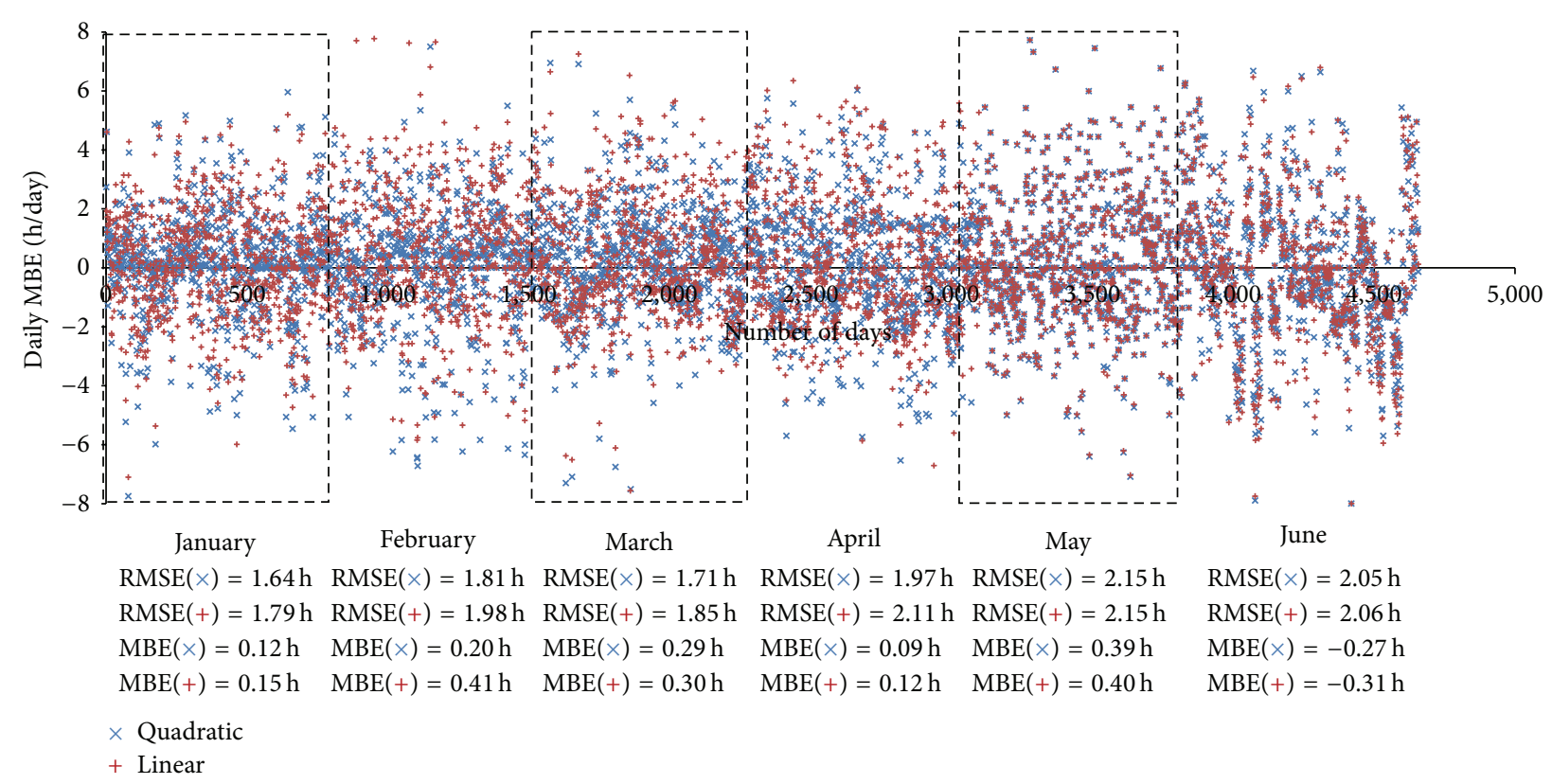

FIGURE 3: Daily MBE values of quadratic and linear models for six months for all stations.

satellite-derived cloud cover index and the measured sunshine duration much better than the linear correlations for the first four months of the year (Tables 1 and 2). Monthly mean RMSE values obtained by quadratic correlations were lower than the linear model for each month and for 115 cases (six months $\times 25$ stations $=$ total of 150 cases $)$. Nearly the same coefficients of determination were produced for both quadratic and linear correlations for the months of May and June, and because of this nearly the same MBE and RMSE values were observed. In these calculations we have assumed that the first six months of the year represent the whole year accurately enough for Turkey because the representative stations chosen for the study reflect all possible climatic behaviors of the country for the whole year.

The daily values of the MBE were calculated for each method and pooled together for all stations (Figure 3). Monthly mean values of RMSE and MBE values were also given in Figure 3. In order to better understand Figure 3, the number of days when mean bias error falls into a specified range was also determined and given in Table 3. It was seen that quadratic correlation gives better estimations than the linear correlation for all the considered ranges. Table 3 also indicated that quadratic model behaves better than linear model if the satellite-derived cloud cover index is coherent with the observed sunshine duration at ground due to its nature. It was also deduced that both methodologies generally overestimated the ground measured results. This was expected because TSMS stations measured zero sunshine duration as $16 \%$ of total days but both models estimated only about $8 \%$ as zero.

Overestimations were dominant especially for the Istanbul, Kocaeli, Rize, Trabzon, Samsun, Afyon, and Erzincan stations. This was expected because these stations (except Erzincan and Afyon) are located at the coasts of Black Sea
Region of Turkey in which Black Sea Mountain chains lie from west to east along the coastline and hold the rain clouds and cause to have the greatest amount of rainfall (2200 millimeters annually). Underestimations were dominant for Antalya, Van, Hakkari, Izmir, Denizli, and S.Urfa stations. Antalya, Izmir, and Denizli stations are located in Aegean Coasts and Southern Aegean which is highly affected by Mediterranean climate, respectively. S.Urfa station is located in southeast Anatolia which is under the influence of Mediterranean and continental climate. Van and Hakkari are located in the southern part of east Anatolia which have dry continental climate. Lower sunshine duration values were obtained for the months of January and February and higher values were obtained for March, April, and June. This is because January and February are the months of winter having generally very cloudy days; on the other side, April and May are the months of spring and June is the first month of summer.

Several sources of errors can affect the accuracies of the models. On some days the cloud cover index could not be calculated correctly if the clouds move rapidly in those days because MODIS sensors record images at two definite times within a definite time interval. If the weather conditions of calibrated stations are different from the weather condition of one or more testing stations for the considered month or the number of calibration stations is not enough, this also increases the error because the regression coefficients represent average weather characteristics of the calibration stations. A small hole in clouds may give a chance to record bright sunshine hours by the sunshine recorder, but satellite sensors could not detect any hole because of their $250 \mathrm{~m}$ pixel resolution. For some cases a pixel or group of pixels can be recorded as fully overcast (meaning high cloud cover ratio) by the satellite sensors, but some types of clouds 
TABLE 2: Comparison of satellite estimates with the measured monthly mean daily sum sunshine duration for nine calibrations (bold) and 16 randomly selected testing stations (all units are in hours per day).

\begin{tabular}{|c|c|c|c|c|c|c|c|}
\hline & Linear & Quadratic & Measured & MBE (linear) & MBE (quadratic) & RMSE (linear) & RMSE (quadratic) \\
\hline \multicolumn{8}{|l|}{ January } \\
\hline Istanbul & 1.7928 & 1.9577 & 1.3935 & 0.3993 & 0.5642 & 1.5324 & 1.3024 \\
\hline Ankara & 2.1441 & 2.0044 & 1.7065 & 0.4376 & 0.2979 & 1.4067 & 1.1505 \\
\hline Konya & 2.1946 & 1.8313 & 1.8806 & 0.3140 & -0.0493 & 2.3237 & 2.2908 \\
\hline İzmir & 3.0198 & 3.0043 & 3.2452 & -0.2254 & -0.2409 & 1.7792 & 1.7315 \\
\hline Antalya & 2.7916 & 3.0197 & 3.6000 & -0.8084 & -0.5803 & 1.7828 & 1.4550 \\
\hline Samsun & 2.5915 & 2.9457 & 3.1871 & -0.5956 & -0.2414 & 1.6356 & 1.6121 \\
\hline S.Urfa & 2.1343 & 2.4201 & 2.0548 & 0.0795 & 0.3653 & 1.7327 & 1.4579 \\
\hline Erzincan & 2.3653 & 2.3253 & 2.4167 & -0.0514 & -0.0914 & 1.2834 & 1.2558 \\
\hline Muş & 1.7532 & 1.3933 & 0.4931 & 1.2601 & 0.9002 & 1.8716 & 1.5403 \\
\hline Kocaeli & 1.8387 & 1.9538 & 1.4548 & 0.3839 & 0.4990 & 1.8006 & 1.5632 \\
\hline Bursa & 2.0368 & 1.8720 & 1.6613 & 0.3755 & 0.2107 & 1.6200 & 1.3810 \\
\hline Balikesir & 2.4440 & 2.2319 & 1.8258 & 0.6182 & 0.4061 & 2.0704 & 2.0228 \\
\hline Eskişehir & 1.3756 & 1.4650 & 1.8032 & -0.4276 & -0.3382 & 2.2029 & 2.0016 \\
\hline Afyon & 1.8311 & 1.8313 & 1.8555 & -0.0244 & -0.0242 & 1.8915 & 1.8403 \\
\hline Denizli & 2.9402 & 2.9391 & 2.4032 & 0.5370 & 0.5359 & 2.3196 & 2.2167 \\
\hline Niğde & 2.8770 & 2.7441 & 2.9750 & -0.0980 & -0.2309 & 1.8254 & 1.7893 \\
\hline Sivas & 2.1674 & 2.0803 & 2.0355 & 0.1319 & 0.0448 & 1.4855 & 1.3433 \\
\hline Malatya & 1.4650 & 1.6239 & 1.6355 & -0.1705 & -0.0116 & 1.6790 & 1.1835 \\
\hline Gaziantep & 1.8041 & 1.9854 & 1.8867 & -0.0826 & 0.0987 & 1.3239 & 0.9408 \\
\hline K.Maras & 1.5045 & 1.9258 & 1.2871 & 0.2174 & 0.6387 & 1.6900 & 1.2947 \\
\hline Diyarbakir & 2.1520 & 2.2601 & 2.2793 & -0.1273 & -0.0192 & 2.3862 & 2.3819 \\
\hline Van & 3.1600 & 3.0122 & 4.7148 & -1.5548 & -1.7026 & 1.9633 & 2.0902 \\
\hline Hakkari & 2.5198 & 2.2500 & 2.3516 & 0.1682 & -0.1016 & 2.0855 & 2.0649 \\
\hline Trabzon & 3.0489 & 3.3608 & 3.0133 & 0.0356 & 0.3475 & 1.5150 & 1.3695 \\
\hline Rize & 3.2841 & 3.5981 & 2.4581 & 0.8260 & 1.1400 & 1.5896 & 1.7696 \\
\hline \multicolumn{8}{|l|}{ February } \\
\hline Istanbul & 4.0940 & 3.8168 & 3.5250 & 0.5690 & 0.2918 & 1.6459 & 1.3671 \\
\hline Ankara & 4.5117 & 4.4442 & 4.3179 & 0.1938 & 0.1263 & 1.7029 & 1.6239 \\
\hline Konya & 5.0346 & 4.7913 & 4.8250 & 0.2096 & -0.0337 & 2.2234 & 2.0203 \\
\hline İzmir & 5.3007 & 5.3028 & 5.3034 & $-\mathbf{0 . 0 0 2 7}$ & -0.0006 & 1.7670 & 1.2680 \\
\hline Antalya & 5.1613 & 5.3444 & 5.9851 & -0.8238 & -0.6407 & 1.8256 & 1.4690 \\
\hline Samsun & 4.0724 & 3.8652 & 3.1607 & 0.9117 & 0.7045 & 2.0856 & 1.8941 \\
\hline S.Urfa & 3.2544 & 3.2245 & 3.2621 & -0.0077 & -0.0376 & 1.6028 & 1.5464 \\
\hline Erzincan & 3.0483 & 2.7781 & 2.4807 & 0.5676 & 0.2974 & 1.9302 & 1.7362 \\
\hline Muş & 2.4452 & 2.0051 & 1.8601 & 0.5851 & 0.1450 & 2.2032 & 2.1093 \\
\hline Kocaeli & 3.8753 & 3.5421 & 2.9964 & 0.8789 & 0.5457 & 2.1205 & 2.0902 \\
\hline Bursa & 3.4372 & 3.0495 & 3.5000 & -0.0628 & -0.4505 & 2.7164 & 2.6584 \\
\hline Balikesir & 3.7980 & 3.5921 & 3.7185 & 0.0795 & -0.1264 & 1.8622 & 1.8080 \\
\hline Eskişehir & 3.8054 & 3.3375 & 1.9396 & 1.8658 & 1.3979 & 2.5252 & 2.8331 \\
\hline Afyon & 4.6686 & 4.5208 & 3.8500 & 0.8186 & 0.6708 & 2.1380 & 1.9314 \\
\hline Denizli & 3.5368 & 3.9574 & 4.3000 & -0.7632 & -0.3426 & 1.5375 & 1.3944 \\
\hline Niğde & 4.3091 & 4.1889 & 3.8607 & 0.4484 & 0.3282 & 1.9616 & 1.8392 \\
\hline Sivas & 3.9775 & 3.6334 & 3.1111 & 0.8664 & 0.5223 & 1.9920 & 1.8818 \\
\hline Malatya & 3.2444 & 2.8883 & 2.6250 & 0.6194 & 0.2633 & 2.0302 & 1.5322 \\
\hline Gaziantep & 2.7212 & 2.7217 & 2.7929 & -0.0717 & -0.0712 & 1.6176 & 1.4282 \\
\hline K.Maras & 4.1772 & 3.8177 & 2.3571 & 1.8201 & 1.4606 & 2.4602 & 2.0244 \\
\hline Diyarbakir & 3.7779 & 3.5816 & 2.9370 & 0.8409 & 0.6446 & 2.3608 & 2.2903 \\
\hline Van & 4.2746 & 3.9925 & 4.5560 & -0.2814 & -0.5635 & 1.6319 & 1.5651 \\
\hline Hakkari & 3.5113 & 3.1845 & 4.1846 & -0.6733 & -1.0001 & 2.0490 & 2.3756 \\
\hline Trabzon & 3.2536 & 2.9904 & 2.2714 & 0.9822 & 0.7190 & 1.7111 & 1.1320 \\
\hline Rize & 3.6210 & 3.1900 & 2.2107 & 1.4103 & 0.9793 & 2.0427 & 1.6651 \\
\hline
\end{tabular}


TABLE 2: Continued.

\begin{tabular}{|c|c|c|c|c|c|c|c|}
\hline & Linear & Quadratic & Measured & MBE (linear) & MBE (quadratic) & RMSE (linear) & RMSE (quadratic) \\
\hline \multicolumn{8}{|l|}{ March } \\
\hline Istanbul & 6.7322 & 6.8391 & 5.9419 & 0.7903 & 0.8972 & 2.2281 & 2.1541 \\
\hline Ankara & 5.8987 & 5.9367 & 6.4613 & -0.5626 & -0.5246 & 1.4852 & 1.4633 \\
\hline Konya & 6.5665 & 6.5924 & 7.0167 & -0.4502 & -0.4243 & 1.9564 & 1.9143 \\
\hline İzmir & 6.9961 & 6.8832 & 7.5586 & -0.5625 & -0.6754 & 1.6497 & 1.6261 \\
\hline Antalya & 6.9993 & 7.1057 & 7.6193 & -0.6200 & -0.5136 & 1.9247 & 1.8457 \\
\hline Samsun & 4.8761 & 4.8877 & 4.0839 & 0.7922 & 0.8038 & 1.7669 & 1.4618 \\
\hline S.Urfa & 6.8667 & 6.8559 & 6.8677 & -0.0010 & -0.0118 & 1.8766 & 1.7569 \\
\hline Erzincan & 5.6839 & 5.5089 & 5.2967 & 0.3872 & 0.2122 & 1.9740 & 1.9065 \\
\hline Muş & 5.4660 & 5.4748 & 5.6226 & -0.1566 & -0.1478 & 2.0922 & 1.8824 \\
\hline Kocaeli & 5.9859 & 5.9283 & 5.1000 & 0.8859 & 0.8283 & 2.6552 & 2.6106 \\
\hline Bursa & 6.6200 & 6.6498 & 5.1839 & 1.4361 & 1.4659 & 2.2076 & 2.1408 \\
\hline Balikesir & 6.6250 & 6.4974 & 5.7806 & 0.8444 & 0.7168 & 1.7574 & 1.6446 \\
\hline Eskişehir & 6.4546 & 6.5332 & 6.4733 & -0.0187 & 0.0599 & 1.9970 & 1.8930 \\
\hline Afyon & 6.6951 & 6.7657 & 5.8225 & 0.8726 & 0.9432 & 1.8023 & 1.6520 \\
\hline Denizli & 6.5801 & 6.9242 & 7.1103 & -0.5302 & -0.1861 & 1.5558 & 1.2917 \\
\hline Niğde & 6.1783 & 6.0574 & 6.4161 & -0.2378 & -0.3587 & 1.8657 & 1.6204 \\
\hline Sivas & 5.5961 & 5.4714 & 5.6276 & -0.0315 & -0.1562 & 1.5140 & 1.2549 \\
\hline Malatya & 7.0045 & 7.0458 & 7.1420 & -0.1375 & -0.0962 & 1.6701 & 1.4141 \\
\hline Gaziantep & 7.0171 & 7.0236 & 6.3065 & 0.7106 & 0.7171 & 1.6365 & 1.5009 \\
\hline K.Maras & 7.3102 & 7.3789 & 6.8172 & 0.4930 & 0.5617 & 1.3902 & 1.3476 \\
\hline Diyarbakir & 6.8572 & 6.9339 & 6.8069 & 0.0503 & 0.1270 & 1.5596 & 1.5750 \\
\hline Van & 6.9557 & 6.8747 & 7.4129 & -0.4572 & -0.5382 & 1.7989 & 1.6299 \\
\hline Hakkari & 6.5429 & 6.6293 & 7.3225 & -0.7796 & -0.6932 & 1.6021 & 1.4218 \\
\hline Trabzon & 4.8752 & 4.9215 & 3.9355 & 0.9397 & 0.9860 & 2.1022 & 1.8566 \\
\hline Rize & 5.4567 & 5.6812 & 3.5655 & 1.8912 & 2.1157 & 2.1822 & 1.9045 \\
\hline \multicolumn{8}{|l|}{ April } \\
\hline Istanbul & 6.9482 & 7.0329 & 5.8000 & 1.1482 & 1.2329 & 2.5907 & 2.3939 \\
\hline Ankara & 6.6835 & 6.7739 & 7.0700 & -0.3865 & -0.2961 & 1.6366 & 1.5213 \\
\hline Konya & 7.6229 & 7.4703 & 7.6600 & -0.0371 & -0.1897 & 2.2064 & 2.0517 \\
\hline İzmir & 7.5452 & 7.4219 & 7.1100 & 0.4352 & 0.3119 & 2.4532 & 2.2244 \\
\hline Antalya & 8.1610 & 8.2247 & 8.2900 & -0.1290 & -0.0653 & 1.6104 & 1.5784 \\
\hline Samsun & 6.7009 & 6.7323 & 6.4733 & 0.2276 & 0.2590 & 2.1562 & 2.1140 \\
\hline S.Urfa & 7.9494 & 7.8532 & 7.9967 & -0.0473 & -0.1435 & 1.7244 & 1.6873 \\
\hline Erzincan & 7.2490 & 6.9552 & 6.7800 & 0.4690 & 0.1752 & 1.6408 & 1.6476 \\
\hline Muş & 6.7796 & 7.0072 & 7.9333 & -1.1537 & -0.9261 & 1.9053 & 1.8079 \\
\hline Kocaeli & 6.8726 & 6.8999 & 5.8000 & 1.0726 & 1.0999 & 2.5616 & 2.4413 \\
\hline Bursa & 7.2095 & 7.0325 & 5.8586 & 1.3509 & 1.1739 & 2.8044 & 1.9153 \\
\hline Balikesir & 6.7299 & 6.6719 & 5.8200 & 0.9099 & 0.8519 & 2.9419 & 2.7986 \\
\hline Eskişehir & 7.4455 & 7.2296 & 6.8276 & 0.6179 & 0.4020 & 1.9908 & 1.6979 \\
\hline Afyon & 7.0270 & 7.0475 & 6.0888 & 0.9382 & 0.9587 & 2.2017 & 1.9771 \\
\hline Denizli & 6.6130 & 6.6534 & 6.6800 & -0.0670 & -0.0266 & 2.4919 & 2.2947 \\
\hline Niğde & 6.9644 & 6.8397 & 7.9897 & -1.0253 & -1.1500 & 2.1735 & 2.3899 \\
\hline Sivas & 6.7828 & 6.7879 & 8.1414 & -1.3586 & -1.3535 & 2.3130 & 2.0624 \\
\hline Malatya & 7.7719 & 7.8371 & 8.4000 & -0.6281 & -0.5629 & 2.2272 & 2.2196 \\
\hline Gaziantep & 7.3816 & 7.2651 & 7.3000 & 0.0816 & -0.0349 & 1.6979 & 2.0035 \\
\hline K.Maras & 7.1555 & 7.0497 & 7.4367 & -0.2812 & -0.3870 & 1.9061 & 1.7924 \\
\hline Diyarbakir & 7.1298 & 6.9476 & 6.4786 & 0.6512 & 0.4690 & 2.0347 & 1.7418 \\
\hline Van & 7.0534 & 6.9587 & 8.1793 & -1.1259 & -1.2206 & 2.0717 & 1.9336 \\
\hline Hakkari & 6.7590 & 6.6472 & 6.9345 & -0.1755 & -0.2873 & 2.4290 & 2.2053 \\
\hline Trabzon & 5.6838 & 5.8542 & 5.2833 & 0.4005 & 0.5709 & 1.3718 & 1.4159 \\
\hline Rize & 6.0230 & 6.5265 & 5.6000 & 0.4230 & 0.9265 & 1.7001 & 1.5743 \\
\hline
\end{tabular}


TABLE 2: Continued.

\begin{tabular}{|c|c|c|c|c|c|c|c|}
\hline & Linear & Quadratic & Measured & MBE (linear) & MBE (quadratic) & RMSE (linear) & RMSE (quadratic) \\
\hline \multicolumn{8}{|l|}{ May } \\
\hline Istanbul & 9.4936 & 9.4817 & 8.9828 & 0.5108 & 0.4989 & 1.7420 & 1.7376 \\
\hline Ankara & 8.5037 & 8.6061 & 9.1429 & -0.6392 & -0.5368 & 2.0170 & 2.0194 \\
\hline Konya & 8.9324 & 8.9159 & 9.3700 & -0.4376 & -0.4541 & 1.9635 & 1.9774 \\
\hline İzmir & 9.3646 & 9.3490 & 9.6276 & -0.2630 & -0.2786 & 1.1739 & 1.1759 \\
\hline Antalya & 10.0414 & 10.0343 & 11.0931 & -1.0517 & -1.0588 & 1.9419 & 1.9453 \\
\hline Samsun & 7.7030 & 7.6705 & 5.7267 & 1.9763 & 1.9438 & 3.0719 & 3.0575 \\
\hline S.Urfa & 9.4058 & 9.3917 & 10.1933 & -0.7875 & -0.8016 & 1.7308 & 1.7437 \\
\hline Erzincan & 8.7553 & 8.7414 & 7.0929 & 1.6624 & 1.6485 & 2.1078 & 2.0998 \\
\hline Muş & 8.2651 & 8.2405 & 8.6179 & -0.3528 & -0.3774 & 1.9574 & 1.9663 \\
\hline Kocaeli & 8.0218 & 7.9916 & 7.1700 & 0.8518 & 0.8216 & 2.3537 & 2.3618 \\
\hline Bursa & 8.3878 & 8.3615 & 8.8300 & -0.4422 & -0.4685 & 2.0694 & 2.0778 \\
\hline Balikesir & 9.6007 & 9.4997 & 9.2200 & 0.3807 & 0.2797 & 2.3755 & 2.3672 \\
\hline Eskişehir & 9.5605 & 9.5484 & 8.9172 & 0.6433 & 0.6312 & 2.5140 & 2.5176 \\
\hline Afyon & 9.1356 & 9.1191 & 8.4407 & 0.6949 & 0.6784 & 1.9207 & 1.9115 \\
\hline Denizli & 9.8980 & 9.9280 & 10.1586 & -0.2606 & -0.2306 & 1.6053 & 1.6178 \\
\hline Niğde & 9.1536 & 9.1390 & 9.1500 & 0.0036 & -0.0110 & 2.2451 & 2.2400 \\
\hline Sivas & 8.7601 & 8.7401 & 8.1323 & 0.6278 & 0.6078 & 2.6354 & 2.6338 \\
\hline Malatya & 8.7190 & 8.6985 & 9.2964 & -0.5774 & -0.5979 & 2.3435 & 2.3584 \\
\hline Gaziantep & 9.4288 & 9.4276 & 7.9667 & 1.4621 & 1.4609 & 2.1911 & 2.1906 \\
\hline K.Maras & 9.6964 & 9.6857 & 8.7067 & 0.9897 & 0.9790 & 1.4969 & 1.4951 \\
\hline Diyarbakir & 9.1645 & 9.1480 & 7.9600 & 1.2045 & 1.1880 & 2.6317 & 2.6338 \\
\hline Van & 8.4553 & 8.4302 & 8.7207 & -0.2654 & -0.2905 & 2.0592 & 2.0790 \\
\hline Hakkari & 8.3256 & 8.3022 & 8.6733 & -0.3477 & -0.3711 & 2.1357 & 2.1427 \\
\hline Trabzon & 7.2095 & 7.1711 & 4.9276 & 2.2819 & 2.2435 & 2.7924 & 2.7685 \\
\hline Rize & 7.2468 & 7.2062 & 5.0593 & 2.1875 & 2.1469 & 2.8585 & 2.8461 \\
\hline \multicolumn{8}{|l|}{ June } \\
\hline Istanbul & 9.8309 & 9.8057 & 9.2800 & 0.5509 & 0.5257 & 1.7893 & 1.9087 \\
\hline Ankara & 10.1674 & 10.2407 & 10.3379 & -0.1705 & -0.0972 & 1.7111 & 1.6759 \\
\hline Konya & 10.2435 & 10.3271 & 9.8551 & 0.3884 & 0.4720 & 1.5196 & 1.5437 \\
\hline İzmir & 10.5845 & 10.5974 & 11.1300 & -0.5455 & -0.5326 & 1.3678 & 1.4185 \\
\hline Antalya & 9.0468 & 9.2680 & 12.1000 & -3.0532 & -2.8320 & 3.3680 & 3.1692 \\
\hline Samsun & 9.9456 & 9.9460 & 8.2483 & 1.6973 & 1.6977 & 2.2473 & 2.3002 \\
\hline S.Urfa & 10.1520 & 10.3440 & 12.5500 & -2.3980 & -2.2060 & 2.3543 & 2.1503 \\
\hline Erzincan & 11.3069 & 11.2671 & 9.0892 & 2.2177 & 2.1779 & 2.4117 & 2.4020 \\
\hline Muş & 10.2631 & 10.3630 & 12.1036 & -1.8405 & -1.7406 & 2.2209 & 2.1225 \\
\hline Kocaeli & 10.1298 & 10.1446 & 9.0038 & 1.1260 & 1.1408 & 1.7102 & 1.7169 \\
\hline Bursa & 10.5175 & 10.4265 & 9.6533 & 0.8642 & 0.7732 & 2.2143 & 2.2663 \\
\hline Balikesir & 10.9929 & 10.9862 & 11.1000 & -0.1071 & -0.1138 & 2.0205 & 1.9943 \\
\hline Eskişehir & 10.2745 & 10.2521 & 9.9651 & 0.3094 & 0.2870 & 1.7138 & 1.7733 \\
\hline Afyon & 9.8033 & 9.7458 & 9.6555 & 0.1478 & 0.0903 & 2.1544 & 2.1869 \\
\hline Denizli & 10.8819 & 10.8333 & 11.1103 & -0.2284 & -0.2770 & 1.1217 & 1.1125 \\
\hline Niğde & 11.1541 & 11.1511 & 11.7000 & -0.5459 & -0.5489 & 2.0301 & 2.0475 \\
\hline Sivas & 10.3470 & 10.4055 & 10.7724 & -0.4254 & -0.3669 & 2.1362 & 2.1982 \\
\hline Malatya & 10.7174 & 10.7711 & 12.2893 & -1.5719 & -1.5182 & 1.2182 & 1.8191 \\
\hline Gaziantep & 10.6259 & 10.6899 & 9.8414 & 0.7845 & 0.8485 & 1.3246 & 1.3215 \\
\hline K.Maras & 9.4012 & 9.5667 & 10.6276 & -1.2264 & -1.0609 & 2.3227 & 2.2903 \\
\hline Diyarbakir & 9.3298 & 9.5493 & 12.0893 & -2.7595 & -2.5400 & 2.9829 & 2.7528 \\
\hline Van & 11.5642 & 11.5205 & 12.7138 & -1.1496 & -1.1933 & 1.2953 & 1.3488 \\
\hline Hakkari & 9.5499 & 9.7931 & 12.9407 & -3.3908 & -3.1476 & 3.3909 & 3.1609 \\
\hline Trabzon & 9.4492 & 9.3451 & 7.8591 & 1.5901 & 1.4860 & 2.5750 & 2.5661 \\
\hline Rize & 9.2694 & 9.0417 & 7.2391 & 2.0303 & 1.8026 & 2.3278 & 2.1988 \\
\hline
\end{tabular}


TABLE 3: Total number of days with MBE within a specified range and corresponding total percentages for the whole study period.

\begin{tabular}{lcccc}
\hline MBE classes & Quadratic & Linear & Quadratic (\%) & Linear (\%) \\
\hline-0.5 to 0.5 & 1246 & 1031 & 27 & 22 \\
-1.0 to 1.0 & 2091 & 1836 & 46 & 40 \\
-1.5 to 1.5 & 2860 & 2612 & 63 & 57 \\
-2.0 to 2.0 & 3402 & 3192 & 75 & 70 \\
\hline
\end{tabular}

permit the sunshine to reach the ground and be recorded by the sunshine recorder. Also instrumental and manmade problems decrease the accuracy.

The overall RMSE and MBE values were calculated as $1.89 \mathrm{~h}$ and $0.14 \mathrm{~h}$ for quadratic model, respectively. These results are consistent with those of previous satellite-based studies in the literature. RMSE and MBE ranged from $0.54 \mathrm{~h}$ to $2.79 \mathrm{~h}$ and $-1.82 \mathrm{~h}$ to $1.93 \mathrm{~h}$, respectively, in the study of Kandirmaz [21], in which four images of Meteosat in a day were used for the estimation of daily sunshine duration over Turkey. MBE error ranged between -0.2 and -0.6 and $\mathrm{SD}$ (standard deviation) ranged between $1.6 \mathrm{~h}$ and $2.2 \mathrm{~h}$, respectively, when the cloud classification data from SEVIRI was used for the United Kingdom [22]. Shamim et al. [23] reported that RMSE and MBE values were ranged between $0.66 \mathrm{~h}$ and $2.31 \mathrm{~h}$ and $-0.19 \mathrm{~h}$ and $2.31 \mathrm{~h}$, respectively.

\section{Conclusions}

Daily sunshine duration values were estimated using MODIS LEVEL 1-B data and linear and quadratic models for 25 stations in Turkey for the first six months of 2004. Accuracies of these models were then compared. It has been deduced that if the considered month has many overcast days then the quadratic correlation defines statistical relation between the satellite-derived cloud cover index and the measured sunshine duration better than linear correlation. However, if this is not the case, behavior of both quadratic and linear models is almost similar.

Although the MODIS data was obtained twice in a day, the resulting accuracy is comparable with the previous studies which have been done with geostationary satellite data offering many observations in a day. This means that daily sunshine duration values over a large area can be estimated also by using images of a polar orbiting satellite for regions where there is no possibility of having any related data. Many sources of error can degrade the performances of the models presented here but satellite-based estimations give us a chance to produce much accurate spatially continuous sunshine duration maps as compared to other methods when distances between stations are large.

\section{Conflict of Interests}

The authors declare that there is no conflict of interests regarding the publication of this paper.

\section{References}

[1] A. Sanchez-Lorenzo, J. Calbó, M. Brunetti, and C. Deser, "Dimming/brightening over the Iberian Peninsula: trends in sunshine duration and cloud cover and their relations with atmospheric circulation," Journal of Geophysical Research D: Atmospheres, vol. 114, no. 10, Article ID D00d09, 2009.

[2] A. Angström, "Solar and terrestrial radiation," Quarterly Journal of the Royal Meteorological Society, vol. 50, no. 210, pp. 121-125, 1924.

[3] P. S. Rao, C. K. Saraswathyamma, and M. R. Sethuraj, "Studies on the relationship between yield and meteorological parameters of para rubber tree (Hevea brasiliensis)," Agricultural and Forest Meteorology, vol. 90, no. 3, pp. 235-245, 1998.

[4] J. Shao, "Calculation of sunshine duration and saving of land use in urban building design," Energy and Buildings, vol. 15, no. 3-4, pp. 407-415, 1991.

[5] M. Rebetez and M. Beniston, "Changes in sunshine duration are correlated with changes in daily temperature range this century: an analysis of Swiss climatological data," Geophysical Research Letters, vol. 25, no. 19, pp. 3611-3613, 1998.

[6] P. T. Nastos and A. Matzarakis, "Weather impacts on respiratory infections in Athens, Greece," International Journal of Biometeorology, vol. 50, no. 6, pp. 358-369, 2006.

[7] J. McGrath, J.-P. Selten, and D. Chant, "Long-term trends in sunshine duration and its association with schizophrenia birth rates and age at first registration-data from Australia and the Netherlands," Schizophrenia Research, vol. 54, no. 3, pp. 199-212, 2002.

[8] B. Aksoy, "Variations and trends in global solar radiation for Turkey," Theoretical and Applied Climatology, vol. 58, no. 1-2, pp. 71-77, 1997.

[9] Environment Canada and Atmospheric Environment Service, Canadian climate normals, 1951-1980, 1982.

[10] L. Diabaté, P. Blanc, and L. Wald, "Solar radiation climate in Africa," Solar Energy, vol. 76, no. 6, pp. 733-744, 2004.

[11] S. M. Robaa, "Evaluation of sunshine duration from cloud data in Egypt," Energy, vol. 33, no. 5, pp. 785-795, 2008.

[12] J. D. Tarpley, "Estimating incident solar radiation at the surface from geostationary satellite data," Journal of Applied Meteorology, vol. 18, no. 9, pp. 1172-1181, 1979.

[13] C. Gautier, G. Diak, and S. Masse, "A simple physical model to estimate incident solar radiation at the surface from GOES satellite data," Journal of Applied Meteorology, vol. 19, no. 8, pp. 1005-1012, 1980.

[14] D. Cano, J. M. Monget, M. Albuisson, H. Guillard, N. Regas, and L. Wald, "A method for the determination of the global solar radiation from meteorological satellite data," Solar Energy, vol. 37, no. 1, pp. 31-39, 1986.

[15] G. Dedieu, P. Y. Deschamps, and Y. H. Kerr, "Satellite estimation of solar irradiance at the surface of the earth and of surface albedo using a physical model applied to Meteosat data," Journal of Climate \& Applied Meteorology, vol. 26, no. 1, pp. 79-87, 1987.

[16] M. D. R. Islam and R. H. B. Exell, "Solar radiation mapping from satellite image using a low cost system," Solar Energy, vol. 56, no. 3, pp. 225-237, 1996.

[17] M. Chaabane, A. Ben Djemaa, and A. Kossentini, "Daily and hourly global irradiations in Tunisia extracted from meteosat wefax images," Solar Energy, vol. 57, no. 6, pp. 449-457, 1996.

[18] H. F. Tovar and J. M. Baldasano, "Solar radiation mapping from NOAA AVHRR data in Catalonia, Spain," Journal of Applied Meteorology, vol. 40, no. 11, pp. 1821-1834, 2001. 
[19] H. M. Kandirmaz, L. Yeği Ngil, V. Peştemalci, and N. Emrahoǧlu, "Daily global solar radiation mapping of Turkey using Meteosat satellite data," International Journal of Remote Sensing, vol. 25, no. 11, pp. 2159-2168, 2004.

[20] S. Janjai, P. Pankaew, J. Laksanaboonsong, and P. Kitichantaropas, "Estimation of solar radiation over Cambodia from long-term satellite data," Renewable Energy, vol. 36, no. 4, pp. 1214-1220, 2011.

[21] H. M. Kandirmaz, "A model for the estimation of the daily global sunshine duration from meteorological geostationary satellite data," International Journal of Remote Sensing, vol. 27, no. 22, pp. 5061-5071, 2006

[22] E. Good, "Estimating daily sunshine duration over the UK from geostationary satellite data," Weather, vol. 65 , no. 12 , pp. 324$328,2010$.

[23] M. A. Shamim, R. Remesan, D. Han, N. Ejaz, and A. Elahi, "An improved technique for global daily sunshine duration estimation using satellite imagery," Journal of Zhejiang University: Science A, vol. 13, no. 9, pp. 717-722, 2012.

[24] C. Bertrand, C. Demain, and M. Journee, "Daily sunshine duration over Belgium by combination of station and satellite data," Remote Sensing Letters, vol. 4, no. 8, pp. 735-744, 2013.

[25] J. A. Duffie and W. A. Beckman, Solar Engineering of Thermal Processes, John Wiley \& Sons, New York, NY, USA, 2nd edition, 1991.

[26] S. Rangarajan, M. S. Swaminathan, and A. Mani, "Computation of solar radiation from observations of cloud cover," Solar Energy, vol. 32, no. 4, pp. 553-556, 1984.

[27] X. Yin, "Bright sunshine duration in relation to precipitation, air temperature and geographic location," Theoretical and Applied Climatology, vol. 64, no. 1-2, pp. 61-68, 1999.

[28] D. Matuszko, "Influence of cloudiness on sunshine duration," International Journal of Climatology, vol. 32, no. 10, pp. 15271536, 2012. 

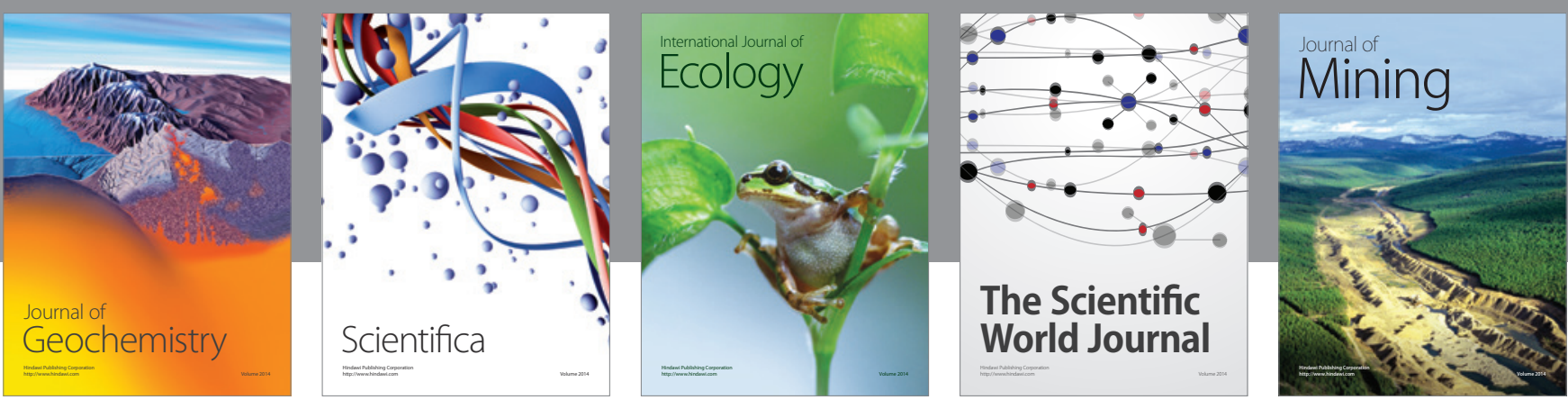

The Scientific World Journal
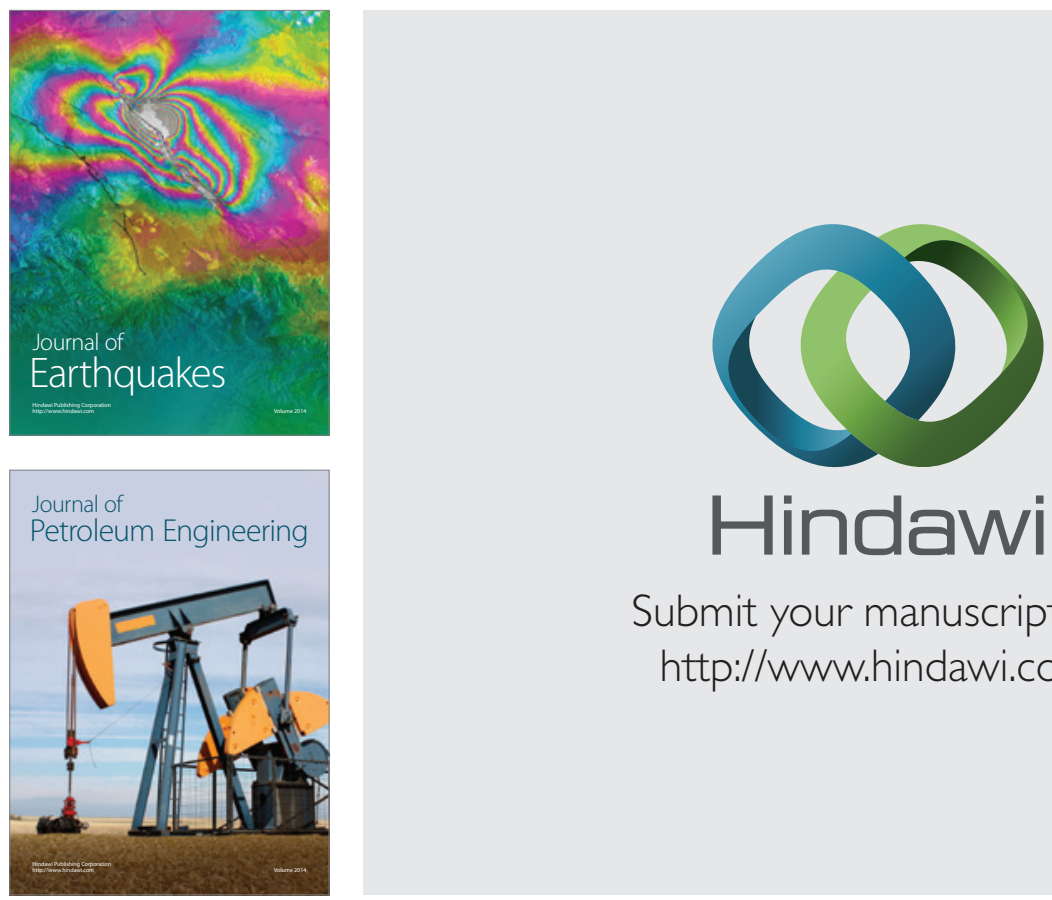

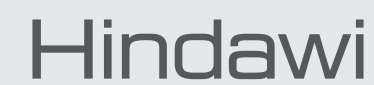

Submit your manuscripts at

http://www.hindawi.com
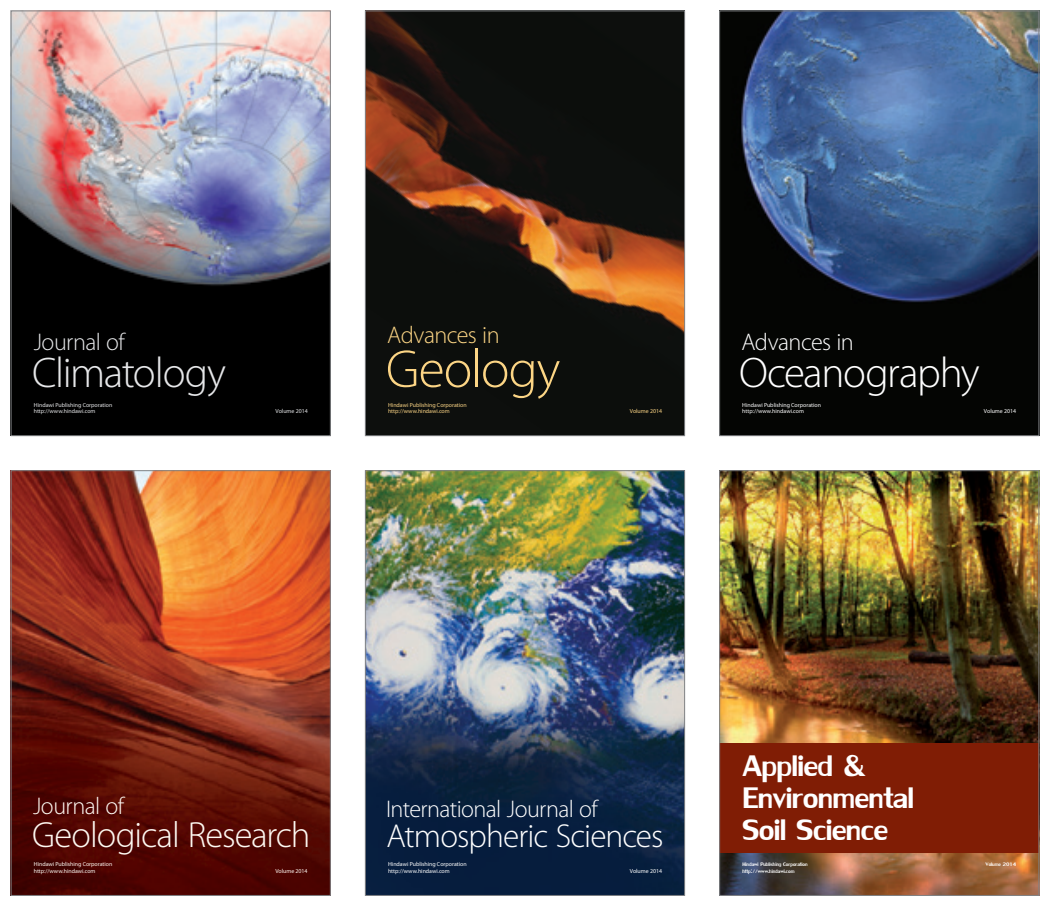
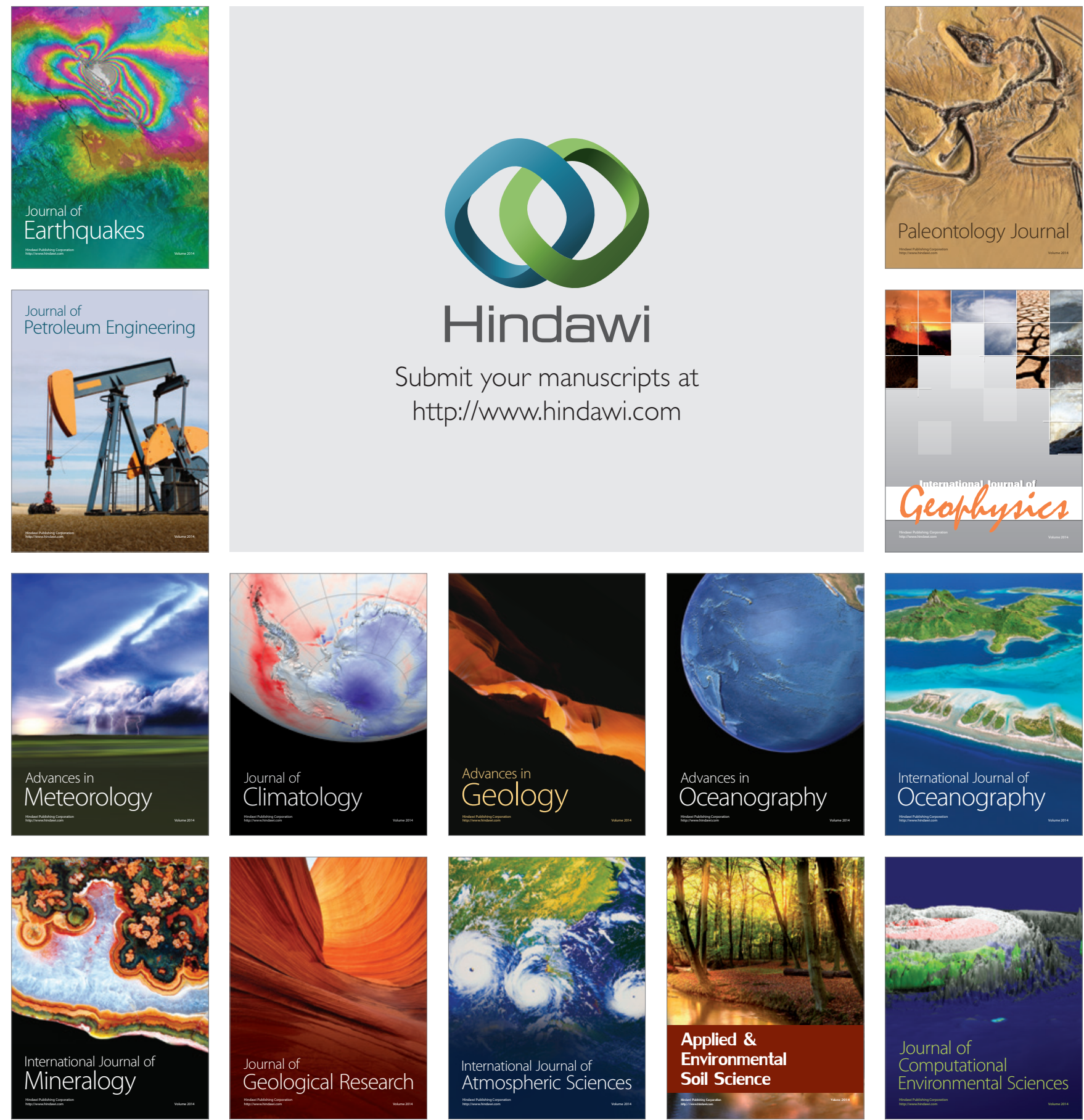